\title{
ESTIMATION OF THE BEHAVIORS OF SELENIUM IN THE NEAR FIELD OF REPOSITORY
}

\author{
SEUNG-SOO KIM*, JAE-HO MIN, MIN-HOON BAIK, GYE-NAM KIM, and JONG-WON CHOI \\ Korea Atomic Energy Research Institute \\ 1045 Daedeok-Daero, Yuseong, Daejeon,305-353, Korea \\ *Corresponding author. E-mail : nsskim@kaeri.re.kr \\ Received February 09, 2012 \\ Accepted for Publication March 29, 2012
}

The sorption of selenium ions onto iron and iron compounds as a disposal container material and its corrosion products, and onto bentonite as a buffer material, was studied to understand the behaviors of selenium in a waste repository. Selenite was sorbed onto commercial magnetite very well in solutions at around $\mathrm{pH} 9$, but silicate hindered their sorption onto both magnetite and ferrite. Unlike commercial magnetite and ferrite, flesh synthesized magnetite, green rust and iron greatly decreased selenium concentration even in a silicate solution. These results might be due to the formation of precipitates, or the sorption of selenide or selenite onto an iron surface at below Eh= $-0.2 \mathrm{~V}$. Red-colored Se(cr) was observed on the surface of a reaction bottle containing iron powder added into a selenite solution. Silicate influences on the sorption onto magnetite and iron for selenide are the same as those for selenite. Even though bentonite adsorbed a slight amount of selenite, the sorption cannot be ignored in the waste repository since a very large quantity of bentonite is used.

KEYWORDS : Sorption, Selenite, Selenide, Iron, Iron Compounds, Bentonite

\section{INTRODUCTION}

Se-79 has emerged as one of the most frequently considered nuclides in the safety assessments of high-level radioactive waste disposal, especially in the disposal of pyro-process wastes [1], due to its long half life $\left(\mathrm{t}_{1 / 2}=3.0\right.$ $\mathrm{x} 10^{5} \sim 1.1 \times 10^{6}$ years) [2-3]. In nature, selenium exists in four different oxidation states, e.g., selenide $\mathrm{Se}(-\mathrm{II})$, elemental selenium $\mathrm{Se}(0)$, selenite $\left(\mathrm{Se}(\mathrm{IV}) \mathrm{O}_{3}{ }^{2-}\right)$, and selenate $\left(\mathrm{Se}(\mathrm{VI}) \mathrm{O}_{4}{ }^{2-}\right)$, which show very different chemical properties. While metal selenides and elemental selenium are slightly soluble and fairly immobile, selenite and selenate are soluble and mobile. Selenium is likely to exist under three oxidation states (-II, 0, IV) in an underground environment, and Se (-II) is likely to precipitate in the presence of $\mathrm{Fe}$ (II) [4].

Owing to their negative charges, selenite and selenate tend to adsorb onto Fe(III) oxides [5]. Iron oxides such as magnetite [6], hematite [7-8] and goethite [9] are known to be capable of binding selenite with high distribution coefficients in groundwater without significantly influencing the ionic strength [9]. Moreover, the presence of Fe(II) in magnetite has shown to help the reduction of selenium oxides to a lower oxidation state $[5,10]$ in a $\mathrm{pH}$ range of 3 8. However, X-ray absorption spectroscopy (XAS) indicated that the oxidation state of selenium did not change when selenite adsorbed onto magnetite at $\mathrm{pH}=4.45 \sim 7.46$ [11]. Thus, there are still many questions regarding the reduction of $\mathrm{Se}(\mathrm{IV})$ in the presence of magnetite.
Based on a Korean concept of disposal for High-Level radioactive Wastes (HLW) or spent fuel, a copper-coated iron canister containing HLW or spent fuel would be installed in a cylindrical bentonite block placed in a borehole located deep underground. Under this geological condition, the iron canister will corrode into magnetite [11] or other iron compounds. Bentonite is a potential candidate for the buffer material between a metal canister and rock because of its swelling property. From an 844-day corrosion test of steel in wet bentonite at $70^{\circ} \mathrm{C}$ under an inert atmosphere, we found that green rust and black corrosion products (amorphous magnetite?) covered the iron specimen [12]. If iron or iron corrosion compounds adsorb selenite or form selenium precipitates with a low solubility, the migration of selenium will be slow in a nuclear waste repository. However, the sorption of selenite can be hindered by other anions in the groundwater. Balistrieri and Chao [13-14] found that silicate ions act as strong competitors against selenite. The sorption of selenite onto clay or rock will also reduce its migration.

In this study, the sorption test of selenite and selenide onto iron and iron compounds, as the disposal container material and its corrosion products, was performed to understand the behaviors of selenium in the waste repository. The reduction of selenite sorbed onto iron was identified using X-ray Diffraction (XRD) techniques. Additionally, the sorption phenomenon of selenite onto bentonite has been examined. 


\section{EXPERIMENTS}

\subsection{Reagents}

The specific surface areas of commercial magnetite ( $\mathrm{Fe}_{3} \mathrm{O}_{4}$, from Showa in Japan), ferrite $\left(\mathrm{Fe}_{2} \mathrm{O}_{3}\right.$, from Showa) and iron (from Cerac in U.S.A.) powders were obtained as $5.1,3.1$ and $1.0 \mathrm{~m}^{2} / \mathrm{g}$, respectively, by applying the Brunauer-Emmet-Teller (BET) equation with nitrogen adsorption isotherms measured using a Micrometrics ASAP instrument. Fresh magnetite and carbonate green rust were prepared using the synthetic methods reported by Dang et al. [15] and Williams et al. [16], respectively. Domestic Ca-bentonite was provided from Korean Volclay, and its composition is shown in Table 1. De-ionized water (DW) produced by a Milli-Q equipment was used for this study. Selenite and selenide stock solutions, and $\mathrm{NaClO}_{4}$ electrolyte medium were prepared by dissolving $\mathrm{Na}_{2} \mathrm{SeO}_{3}$ (from Aldrich), $\mathrm{Na}_{2} \mathrm{Se}$ (from Alfa Aesar), and $\mathrm{NaClO}_{4} \cdot \mathrm{H}_{2} \mathrm{O}$ (from Merck) in DW, respectively. Black-colored Se(cr) (from Aldrich, >99.99\%) was also used for the solubility measurement of selenium. All other reagents used were above pro-analysis grade, and all stock solutions were kept in Teflon ${ }^{\circledR}$ bottles.

Since the sorption of ions on the sorbent can be greatly dependent on their concentration [17] and the concentration of selenium in the repository is anticipated to be low, the sorption behavior of selenite in the low concentration has to be examined. Actually the concentration of selenium in the natural water or groundwater is found at around $10^{-9}$ mol/L [18]. Thus, Se-75 isotope (added $100 \mu \mathrm{g} / \mathrm{mL} \mathrm{Se}$ carrier) as a selenious acid in $0.1 \mathrm{M} \mathrm{HCl}$, purchased from EcKert \& Ziegler Isotope Products, was used for the sorption test in the low selenite concentration with less than $1 \times 10^{-}$ ${ }^{6} \mathrm{~mol} / \mathrm{L}$.

\subsection{Sorption Experiment}

Solution preparation, sorption reaction and sample filtration were performed in an Ar-filled glove box at room temperature. In $20 \mathrm{~mL}$ polypropylene bottles, a measured amount of iron, iron compounds or bentonite was immersed in the prepared solutions which contained the electrolytes, selenium ion, and other anions. The $\mathrm{pH}$ of the solution was then adjusted by adding a small amount of either $\mathrm{NaOH}$ or $\mathrm{HClO}_{4}$ solution. For the solutions containing bentonite, the $\mathrm{pH}$ of the solution was adjusted again after shaking for one day. Since the concentration of the selenium in the solution was not changed after three days reaction time, the bottles were shaken for the sorption reaction for seven days. However, for the sorption of selenite onto the green rust, the sorption reaction was performed for 1, 2, and 3 hours because green rust is very sensitive to oxygen content as low as $10 \mathrm{mg} / \mathrm{L}$ in a glovebox [5]. The final $\mathrm{pH}$ and $\mathrm{Eh}$ of the solutions were measured in the glove box just after sampling.

After sorption reaction, the suspension was filtered through polyethersulfone (PES) micro-filters with a 0.22 $\mu \mathrm{m}$ pore size. To observe the sorption of selenium by the polypropylene bottles and PES filter, a blank test was also performed without a solid. The test was primarily performed at near $\mathrm{pH}$, because the $\mathrm{pH}$ of a domestic granitic groundwater at a depth of $500 \mathrm{~m}$ is assumed to be 8.5 9.5. All experiments were duplicately performed. The concentration of selenium was analyzed using inductively coupled plasmamass spectrometry (ICP-MS, Perkin-Elmer, Elan 6100), and the activity of Se-75 in the solution was measured by using $\gamma$-spectrometry (GEM-30185-P, EG\&G, ORTEC).

The amount of selenium sorbed onto solid (iron, iron compounds or bentonite) was calculated from the concentration difference between before and after the sorption reaction, and the distribution coefficient $\left(\mathrm{K}_{\mathrm{d}}, \mathrm{mL} / \mathrm{g}\right)$ of selenium onto solid was obtained as follows:

$$
K_{d}=\frac{S}{C}=\frac{\left(C_{0}-C\right)}{C} \cdot \frac{V}{M}
$$

where $\mathrm{S}$ is the concentration of selenium sorbed onto the unit mass of solid (mol/g), C is the concentration of selenium remaining in the solution after a sorption reaction $(\mathrm{mol} / \mathrm{mL}), \mathrm{C}_{\mathrm{o}}$ is the initial concentration of the selenium before sorption reaction $(\mathrm{mol} / \mathrm{mL}), \mathrm{M}$ is the mass of the solid $(\mathrm{g})$, and $\mathrm{V}$ is the volume of the solution $(\mathrm{mL})$.

\subsubsection{The Sorption of Selenite and Selenide onto the Iron and Iron Compounds}

Table 2 shows the detailed experiment conditions for the sorption of selenite and selenide onto commercial ferrite, magnetite and iron powders, and freshly synthesized magnetite and green rust powders. The divalent iron (Fe(II)) on the surface of commercial magnetite can be further oxidized to trivalent iron (Fe(III)) by exposure to air. For a comparison with commercial magnetite, ferrite was selected for Fe(III). Since silicate ion is known to hinder the selenite sorption onto magnetite, it was added into some selenite solutions in order to analyze the influence of silicate on the sorption of selenite onto iron and iron compounds. Iron and magnetite pre-saturated with silicate were also

Table 1. Chemical Composition of a Domestic Ca-bentonite

\begin{tabular}{c|c|c|c|c|c|c|c|c|c}
\hline & $\mathrm{SiO}_{2}$ & $\mathrm{Al}_{2} \mathrm{O}_{3}$ & $\mathrm{Fe}_{2} \mathrm{O}_{3}$ & $\mathrm{CaO}$ & $\mathrm{MgO}$ & $\mathrm{K}_{2} \mathrm{O}$ & $\mathrm{Na}_{2} \mathrm{O}$ & $\mathrm{SO}_{3}$ & $\mathrm{MnO}$ \\
\hline Wt. \% & 56.95 & 19.96 & 6.18 & 2.59 & 0.77 & 0.93 & 1.25 & 1.28 & 0.14 \\
\hline
\end{tabular}


used for the sorption test of selenite because they should be saturated with silicate before contacting with selenium ions during the corrosion time of the iron canister in the waste repository. To saturate the magnetite with silicate, the number of reaction site of magnetite was calculated in comparison with the BET surface areas reported in previous studies $[4,19]$. As a result, $11 \mathrm{~g}$ of magnetite powder was added to excess amounts $(1.0 \mathrm{~L}$ of $10 \mathrm{mM})$ of silicate solution. After three days of shaking, the filtered magnetite was collected and dried in a glove box. Iron powder also was saturated with silicate using the same method as magnetite. The ionic strength of all reaction solutions for the selenite sorption onto iron and iron compounds was adjusted to about $0.02 \mathrm{M}$ by adding a $\mathrm{NaClO}_{4}$ solution,

Table 2. The Experimental Conditions and Results for the Sorption of Selenite (Se(IV)) and Selenide (Se(-II)) onto Iron and Iron Compounds

\begin{tabular}{|c|c|c|c|c|c|c|}
\hline \multirow{2}{*}{ Solid } & \multicolumn{3}{|c|}{ Initial composition of reaction solution } & \multirow{2}{*}{ Final $\mathrm{pH}$} & \multirow{2}{*}{$\begin{array}{l}\text { Final } \\
\text { Eh } \\
(\mathrm{V})\end{array}$} & \multirow{2}{*}{$\begin{array}{l}{[\mathrm{Se}]_{\text {final }}} \\
(\mathrm{mol} / \mathrm{L})\end{array}$} \\
\hline & $\begin{array}{l}{[\mathrm{Se}] \text { initial }} \\
(\mathrm{mol} / \mathrm{L})\end{array}$ & $\begin{array}{c}\mathrm{Na}_{2} \mathrm{SiO}_{3} \\
(\mathrm{~mol} / \mathrm{L})\end{array}$ & $\begin{array}{l}\text { Liquid/ Solid } \\
\quad(\mathrm{mL} / \mathrm{g})\end{array}$ & & & \\
\hline \multirow{3}{*}{$\begin{array}{c}\text { Ferrite } \\
\text { (commercial) }\end{array}$} & $\mathrm{Se}(\mathrm{IV}), 1.0 \times 10^{-5}$ & - & \multirow{3}{*}{20} & 9.1 & \multirow{3}{*}{-} & $1.2 \times 10^{-7}$ \\
\hline & $\mathrm{Se}(\mathrm{IV}), 1.0 \times 10^{-5}$ & $1.0 \times 10^{-4}$ & & 8.9 & & $2.4 \times 10^{-7}$ \\
\hline & $\mathrm{Se}(\mathrm{IV}), 1.0 \times 10^{-5}$ & $1.0 \times 10^{-3}$ & & 9.3 & & $5.0 \times 10^{-6}$ \\
\hline \multirow{8}{*}{$\begin{array}{l}\text { Magnetite } \\
\text { (commercial) }\end{array}$} & $\mathrm{Se}(\mathrm{IV}), 1.0 \times 10^{-5}$ & - & \multirow{6}{*}{20} & 9.1 & \multirow{6}{*}{+0.3} & $1.6 \times 10^{-7}$ \\
\hline & $\operatorname{Se}(\mathrm{IV}), 1.0 \times 10^{-5}$ & $1.0 \times 10^{-4}$ & & 8.9 & & $3.3 \times 10^{-7}$ \\
\hline & $\mathrm{Se}(\mathrm{IV}), 1.0 \times 10^{-5}$ & $1.0 \times 10^{-3}$ & & 9.0 & & $5.8 \times 10^{-6}$ \\
\hline & $\operatorname{Se}(\mathrm{IV}), 3.7 \times 10^{-7}$ & - & & 8.8 & & $4.3 \times 10^{-9}$ \\
\hline & $\mathrm{Se}(\mathrm{IV}), 3.7 \times 10^{-7}$ & $1.0 \times 10^{-3}$ & & 8.8 & & $1.3 \times 10^{-7}$ \\
\hline & $\mathrm{Se}(\mathrm{IV}), 3.7 \times 10^{-8}$ & $1.0 \times 10^{-3}$ & & 8.8 & & $1.6 \times 10^{-8}$ \\
\hline & $\mathrm{Se}(-\mathrm{II}), 1.0 \times 10^{-5}$ & - & \multirow{2}{*}{40} & 9.7 & \multirow{2}{*}{$-0.3^{*}$} & $2.0 \times 10^{-7}$ \\
\hline & $\mathrm{Se}(-\mathrm{II}), 1.0 \times 10^{-5}$ & $1.0 \times 10^{-3}$ & & 10.1 & & $1.1 \times 10^{-6}$ \\
\hline \multirow{2}{*}{$\begin{array}{l}\text { Silicate-saturated } \\
\text { commercial } \\
\text { magnetite }\end{array}$} & $\mathrm{Se}(\mathrm{IV}), 3.7 \times 10^{-7}$ & & \multirow{2}{*}{20} & \multirow{2}{*}{9.1} & \multirow{2}{*}{-} & $3.5 \times 10^{-7}$ \\
\hline & $\mathrm{Se}(\mathrm{IV}), 3.5 \times 10^{-8}$ & 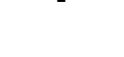 & & & & $3.4 \times 10^{-8}$ \\
\hline \multirow{2}{*}{$\begin{array}{l}\text { Magnetite } \\
\text { (synthetic) }\end{array}$} & $\mathrm{Se}(\mathrm{IV}), 1.0 \times 10^{-5}$ & - & \multirow{2}{*}{40} & 8.2 & \multirow{2}{*}{-0.3} & $<1 \times 10^{-8}$ \\
\hline & $\mathrm{Se}(\mathrm{IV}), 1.0 \times 10^{-5}$ & $1.0 \times 10^{-3}$ & & 7.8 & & $<1 \times 10^{-8}$ \\
\hline \multirow{2}{*}{$\begin{array}{l}\text { Green rust } \\
\text { (synthetic) }\end{array}$} & $\mathrm{Se}(\mathrm{IV}), 1.0 \times 10^{-5}$ & - & \multirow{2}{*}{40} & \multirow{2}{*}{9.0} & \multirow{2}{*}{-0.2} & $3.5 \times 10^{-7}$ \\
\hline & $\mathrm{Se}(\mathrm{IV}), 1.0 \times 10^{-5}$ & $1.0 \times 10^{-3}$ & & & & $2.2 \times 10^{-7}$ \\
\hline \multirow{6}{*}{$\begin{array}{c}\text { Iron } \\
\text { (commercial) }\end{array}$} & $\mathrm{Se}(\mathrm{IV}), 1.0 \times 10^{-5}$ & - & \multirow{6}{*}{20} & \multirow{6}{*}{9.3} & \multirow{6}{*}{$\begin{array}{r}-0.3 \sim \\
-0.4\end{array}$} & $<1.0 \times 10^{-8}$ \\
\hline & $\mathrm{Se}(\mathrm{IV}), 9.0 \times 10^{-6}$ & $1.0 \times 10^{-3}$ & & & & $1.3 \times 10^{-8}$ \\
\hline & $\mathrm{Se}(\mathrm{IV}), 1.9 \times 10^{-8}$ & - & & & & $5.6 \times 10^{-10}$ \\
\hline & $\mathrm{Se}(\mathrm{IV}), 1.9 \times 10^{-8}$ & $1.0 \times 10^{-3}$ & & & & $9.3 \times 10^{-10}$ \\
\hline & $\mathrm{Se}(-\mathrm{II}), 1.0 \times 10^{-5}$ & - & & & & $1.3 \times 10^{-8}$ \\
\hline & $\mathrm{Se}(-\mathrm{II}), 1.0 \times 10^{-5}$ & $1.0 \times 10^{-3}$ & & & & $2.6 \times 10^{-7}$ \\
\hline \multirow{3}{*}{$\begin{array}{l}\text { Silicate-saturated } \\
\text { iron }\end{array}$} & $\mathrm{Se}(\mathrm{IV}), 1.0 \times 10^{-5}$ & & \multirow{3}{*}{20} & \multirow{3}{*}{9.3} & \multirow{3}{*}{$\begin{array}{l}-0.3 \sim \\
-0.43\end{array}$} & $9.0 \times 10^{-8}$ \\
\hline & $\mathrm{Se}(\mathrm{IV}), 1.9 \times 10^{-8}$ & - & & & & $1.6 \times 10^{-9}$ \\
\hline & $\mathrm{Se}(-\mathrm{II}), 1.0 \times 10^{-5}$ & & & & & $<1.0 \times 10^{-8}$ \\
\hline
\end{tabular}

* $2 \mathrm{~mL}$ of $1 \mathrm{~mol} / \mathrm{L}$ hydrazine was added into $18 \mathrm{~mL}$ of selenide solution to maintain a reducing condition. 
which corresponds to a little higher than that of a domestic granitic groundwater.

The weights of the magnetite and green rust added into the selenite solutions were indirectly calculated. After synthesis of magnetite and green rust, the wet compounds were weighed and added into the selenium ion solutions. To know the amount of added compounds, almost identical amount of the remaining wet compounds were sampled, weighed and dried in a glovebox. During drying, the weight difference between the green rust and the oxidized green rust was ignored.

The sorption behavior of selenide, as a reduced species of selenite, may be different from that of selenite. Thus, a selenide sorption test onto commercial magnetite and iron was also performed, and its experimental conditions also are described in Table 2. For the sorption test onto commercial magnetite, hydrazine solution was added to prohibit the oxidation of selenide.

\subsubsection{Measurement of Solubility of Elemental Selenium}

In the reducing condition of radioactive waste repositories, $\mathrm{HSe}^{-}$or $\mathrm{Se}_{4}{ }^{2-}$ will be the dominant dissolved species of selenium [5, 20-21], and elemental Se or $\mathrm{FeSe}_{2}$ is known as the SLSP (Solubility Limiting Solid Phase) at neutral and weak alkaline solutions [4, 21-22]. Thus, the selenite can be changed into $\mathrm{HSe}^{-}, \mathrm{Se}_{4}{ }^{2-}$, elemental $\mathrm{Se}$ or $\mathrm{FeSe}_{2}$ by the addition of iron or iron compounds.

For the observation of the change of selenite oxidation state by iron powder, $3 \mathrm{~g}$ of iron powder was added to $200 \mathrm{~mL}$ of $50 \mathrm{mM}$ selenite solution. During the shaking for seven days, the color of the solution changed to red, and a red precipitate was found on the inside wall of the Teflon reaction bottle. The red precipitate was measured using X-ray Diffractometry (Rigaku, G-MAX 2500).

In order to measure the solubility of selenium in a reducing condition, a red precipitate, found in the Teflon bottle, and commercial black selenium metal powder were put into $0.1 \mathrm{M}$ hydrazine solutions, respectively. After 7, 15 and 22 days, the supernatant was sampled and filtered, and the concentration of selenium was measured.

To identify the maximum concentration of dissolved selenide in a reducing condition, $1 \mathrm{~mL}$ of $1 \mathrm{~mol} / \mathrm{L}$ hydrazine solution was added into $10 \mathrm{~mL}$ of $1 \times 10^{-4}$ and $1 \times 10^{-5} \mathrm{~mol} / \mathrm{L}$ selenide solutions, respectively. The mixtures were shaken for 7 days, and selenium concentration was then measured in the filtrate. As another test, $1 \times 10^{-4} \mathrm{~mol} / \mathrm{L}$ of sodium selenide solution was kept in a glovebox filled with $4 \%$ $\mathrm{H}_{2} / \mathrm{Ar}$ balance for 7 days, and selenium concentration in the filtrate was also measured.

\subsubsection{Sorption of Selenite onto the Bentonite}

Selenite can adsorb onto the bentonite in a waste repository. The decrease of selenite concentration by the addition of bentonite can be due to its adsorption onto bentonite and/or the formation of precipitants with the ions released from bentonite. To identify the cause, a series of washed bentonite was prepared with the following washing procedure: $20 \mathrm{~g}$ of bentonite was shaken in $200 \mathrm{~mL}$ of DW at the $80 \mathrm{rpm}$ for 2 days, the bentonite solution was then centrifuged at $10,000 \mathrm{rpm}$ for more than 10 minutes. Finally, solid was dried at 50 and $120^{\circ} \mathrm{C}$ for 1 day and 3 hours, respectively. Using the same method, bentonite samples washed 2 and 3 times were prepared by rewashing and drying a portion of the bentonite obtained from the previous washing step one after another.

Non-washed bentonite and bentonite washed 1, 2 or 3 times were added into selenite solutions, respectively, as shown in Table 3. After shaking for 7 days, the solutions were filtered by $0.22 \mu \mathrm{m}$ pore size filters or NMWL $10 \mathrm{k}$ ultrafiltration membrane filters. The concentration of selenium in the filtrates was analyzed.

Table 3. Experimental Conditions and Results for the Sorption Test of Selenite onto Bentonites Washed and Unwashed

\begin{tabular}{|c|c|c|c|c|}
\hline Bentonite & $\begin{array}{l}{[\mathrm{Se}]_{\text {initial }}} \\
(\mathrm{mol} / \mathrm{L})\end{array}$ & $\begin{array}{l}\text { Liquid/ Solid } \\
\quad(\mathrm{mL} / \mathrm{g})\end{array}$ & Final $\mathrm{pH}$ & $\mathrm{K}_{\mathrm{d}}{ }^{*}$ \\
\hline Unwashed & $\begin{array}{l}1.0 \times 10^{-6} \\
1.0 \times 10^{-5} \\
1.0 \times 10^{-4}\end{array}$ & 20 & 9.2 & $\begin{array}{c}22.2 \\
15.1 \\
1.2\end{array}$ \\
\hline $\begin{array}{c}\text { Unwashed } \\
1 \text { time washed } \\
2 \text { times washed } \\
3 \text { times washed }\end{array}$ & $\begin{array}{l}1.0 \times 10^{-5} \\
1.0 \times 10^{-5} \\
1.0 \times 10^{-5} \\
1.0 \times 10^{-5}\end{array}$ & 40 & 8.6 & $\begin{array}{l}10.5 \\
5.1 \\
6.7 \\
6.4\end{array}$ \\
\hline
\end{tabular}

"Mean value of diffusion coefficients obtained from the duplicate experiment 


\section{RESULTS AND DISCUSSION}

\subsection{Behaviors of Selenium lons in Solution Contained Iron and Iron Corrosion Compounds}

The sorption results of selenite and selenide onto iron and iron compounds are shown in Table 2. When the green rust was used as an adsorbent, a comparison of selenium concentration in the filtrates after 1, 2 and 3 hours of reaction time indicated that the reaction between selenite and green rust occurred within 1 hour. Table 2 shows that commercial ferrite and magnetite sorb selenite very well at around $\mathrm{pH} 9$ solutions, and the hindrance of silicate on the sorption of selenite is similar in both sorbents. The similar sorption behaviors between commercial magnetite and ferrite can be explained that the oxidation state of iron on the surface of commercial magnetite is similar to that of ferrite due to the exposure to air. When the silicatesaturated magnetite was added into selenite solutions, most selenite also was not sorbed onto the commercial magnetite. These results indicate that silicate hinders the sorption of selenite onto Fe(III).

For the selenide, selenium concentration greatly decreased to $1.1 \times 10^{-6} \mathrm{~mol} / \mathrm{L}$ when the commercial magnetite was added in $1 \times 10^{-5} \mathrm{~mol} / \mathrm{L}$ selenide solution with $1 \times 10^{-3}$ $\mathrm{mol} / \mathrm{L}$ silicate and $0.1 \mathrm{~mol} / \mathrm{L}$ hydrazine (Table 2 ). However, even this result is difficult to insist that selenide was adsorbed onto commercial magnetite, since selenium concentration changed to $5 \times 10^{-6}$ and $1 \times 10^{-6} \mathrm{~mol} / \mathrm{L}$ at $\mathrm{pH} 8.5 \sim 10.0$ and $\mathrm{Eh}=-0.28 \sim-0.35 \mathrm{~V}$ after 7 days when hydrazine was added into $1 \times 10^{-4}$ and $1 \times 10^{-5} \mathrm{~mol} / \mathrm{L}$ of selenide solutions without iron compounds, respectively. A 7-days storage of $1 \times 10^{-4} \mathrm{~mol} / \mathrm{L}$ of sodium selenide solution in a glovebox also decreased selenium concentration to $4 \times 10^{-6} \mathrm{~mol} / \mathrm{L}$ in a final $\mathrm{pH}=8.5$ and $\mathrm{Eh}=-0.35 \mathrm{~V}$ solution.

Contrary to commercial magnetite, both the freshly synthesized magnetite and the green rust decreased the selenium concentration to less than $3.5 \times 10^{-7} \mathrm{~mol} / \mathrm{L}$ even in a silicate solution, as shown in Table 2 . These results might be due to the formation of precipitates and/or the sorption of selenium ions onto these solids without the strong interference of silicate. It can be thought that the sorption on the fleshly synthesized magnetite has greatly occurred because the selenium concentration after reaction with the fleshly synthesized magnetite decreased to very low value such as $<1 \times 10^{-8} \mathrm{~mol} / \mathrm{L}$ (Table 2).

The selenite might be reduced to $\mathrm{HSe}^{-}$under a condition of $\mathrm{pH}=\sim 9$ and $\mathrm{Eh}<-0.3 \mathrm{~V}[20,23]$. The HSe- then formed $\mathrm{FeSe}_{\mathrm{x}}(\mathrm{x}=1$ or 2$)$ [23] or selenium elemental precipitates, or strongly sorbed onto the iron compounds. When iron powder was added into the selenite solutions, selenium concentration was decreased to below $10^{-9} \mathrm{~mol} / \mathrm{L}$, which corresponds to less than the solubility of $\mathrm{Se}(\mathrm{cr})$ or $\mathrm{FeSe}_{2}$ under a reducing condition. In a solution of $\mathrm{pH} 7 \sim 9$ and $\mathrm{Eh}=-0.3 \sim-0.4 \mathrm{~V}$, the solubility of $\mathrm{Se}(\mathrm{cr})$ or $\mathrm{FeSe}_{2}$ is generally known as $5 \times 10^{-7} \sim 1 \times 10^{-9} \mathrm{~mol} / \mathrm{L}$ [19-20, 24-25]. From the solubility test conducted on both the black-colored selenium metal and red precipitate, formed on the surface of the reaction bottle by the addition of the iron powder into selenite solution, about $8 \times 10^{-8} \mathrm{~mol} / \mathrm{L}$ of selenium concentration for both solutions was obtained at $\mathrm{pH}=8.9$ and $\mathrm{Eh}=\sim-0.3 \mathrm{~V}$ for both solids after 7-days reaction time. Therefore the decrease of selenium concentration to less than $10^{-9} \mathrm{~mol} / \mathrm{L}$ by the iron powder indicates that selenide sorption onto iron powder occurs, even though the possibility of the formation of precipitates cannot be excluded The great decrease of selenium concentration by iron powder in the $1 \times 10^{-3} \mathrm{~mol} / \mathrm{L}$ silicate solution and by silicatesaturated iron powder also suggested that $\mathrm{HSe}-$ has a sorption affinity onto iron greater than silicate, since the silicate effect was not as great onto iron as it was onto commercial magnetite, despite the relatively smaller surface area of iron powder than that of commercial magnetite.

X-ray photoelectron spectroscopy [4] and XAS [11, 26-27] studies revealed the absence of $\mathrm{Se}(\mathrm{IV})$ reduction during the sorption onto $\mathrm{Fe}_{3} \mathrm{O}_{4}$ nanoparticles, and Loyo et al. [27] showed that magnetite cannot reduce Se(IV) in basic solutions, since its redox potential is more positive than that of selenite. In contrast, some studies have strongly suggested that $\mathrm{Se}(\mathrm{IV})$ can be reduced by Fe(II) included in green rust [28], magnetite, mackinawite and siderite [29], pyrite [30], and troilite [31]. In this study, the great decrease of selenium concentration by a small amount of addition of freshly synthesized magnetite even in the silicate solution, unlike commercial magnetite, suggests the change of selenite oxidation state. Moreover, red-colored precipitate was formed on the surface of the reaction bottle by the addition of the iron powder into $0.05 \mathrm{~mol} / \mathrm{L}$ of selenite solution, and it was identified as selenium crystal with a hexagonal structure (Fig. 1, ICDD PDF 01-0853).

The sorption results of selenium ions on the iron and iron compounds indicate that the migration of selenium in the waste repository is dependent on the surface state of the metal compounds, selenium species, and redox potential

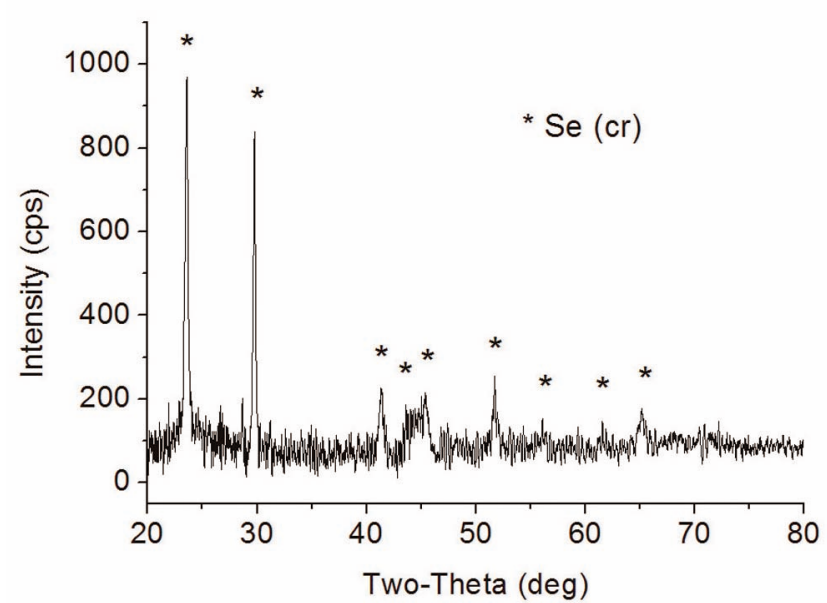

Fig. 1. XRD Pattern of Red Precipitate Formed on the Surface of Reaction Bottle. 


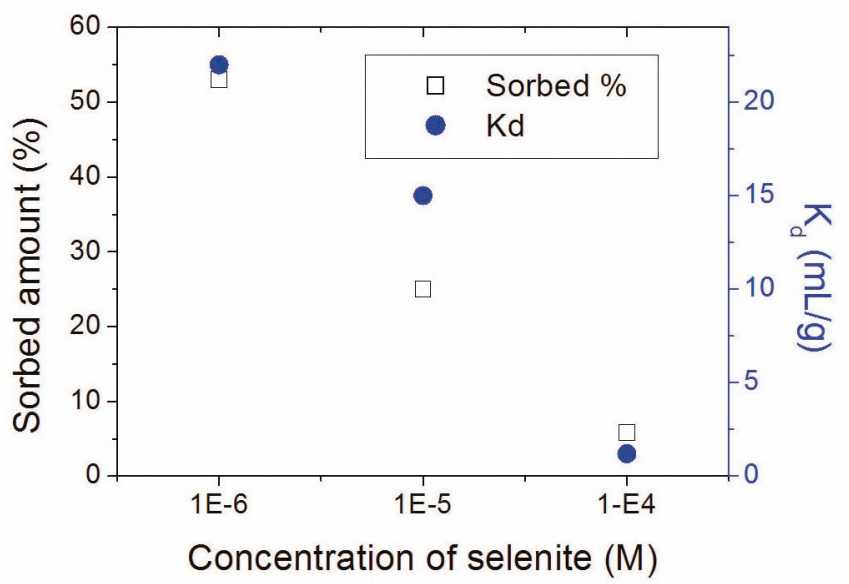

Fig. 2. Sorbed Amount $(\%)$ and Distribution Coefficients $\left(\mathrm{K}_{\mathrm{d}}\right)$ of Selenite onto Unwashed Bentonite as a Function of Selenite Concentration at Water/Bentonite $=20 \mathrm{~mL} / \mathrm{g}$ and $\mathrm{pH}=\sim 9.1$.

and anion concentration of groundwater. If selenite contacts the oxidized surface of magnetite, selenium will migrate rapidly because of the influence of silicate in groundwater. However, if selenite contacts green rust or iron, its mobility will be very low. Fresh magnetite also will retard the selenium migration, while the reduction of selenite by magnetite is controversial in the literatures. In the waste repository, hydrogen produced from the corrosion of the container, and $\mathrm{e}_{\mathrm{aq}}^{-}, \cdot \mathrm{O}_{2}^{-}, \mathrm{H} \bullet, \mathrm{H}_{2}$ and $\mathrm{H}^{+}$produced by the water radiolysis [32] will contribute to make less oxidized iron compounds. However, higher oxidized corrosion products can also be formed by oxygen in the groundwater and $\bullet \mathrm{OH}, \mathrm{O}_{2}$ and $\mathrm{H}_{2} \mathrm{O}_{2}$ as water radiolysis products, and they will hardly capture the selenite or selenide in a nuclear repository.

\subsection{Selenite Sorption onto Bentonite}

The concentration of silicon dissolved from bentonite remained at $3 \times 10^{-4} \sim 7 \times 10^{-4}$ and $1.7 \times 10^{-4} \mathrm{~mol} / \mathrm{L}$ in filtrates through a micro-filter and NMWL 10k ultra-filter, respectively. Thus, the concentration of silicon will be below $1 \times 10^{-3} \mathrm{~mol} / \mathrm{L}$ in neutral and weak alkaline groundwater in a waste repository. After the sorption reaction of selenite onto bentonite, the selenium concentration filtered through the micro-filter was decreased from $0.59 \mathrm{mg} / \mathrm{L}$ to 0.45 $\mathrm{mg} / \mathrm{L}$ after ultrafiltration. These results indicate that few colloids were formed.

As shown in Fig. 2, the sorption percentage of selenite onto bentonite increased as the concentration of selenite decreased. While a slight amount of selenite was sorbed in $10^{-4} \mathrm{~mol} / \mathrm{L}$ of the selenite solution at around $\mathrm{pH} \mathrm{9,} \mathrm{the}$ sorption amount of selenite reached greater than $50 \%$ in $10^{-6} \mathrm{~mol} / \mathrm{L}$. Therefore, the sorption of selenite on bentonite cannot be ignored because the selenium concentration will be lower in the nuclear waste repository, as very large quantity of bentonite is used as a buffer material in the waste repository. However, if the selenite concentration

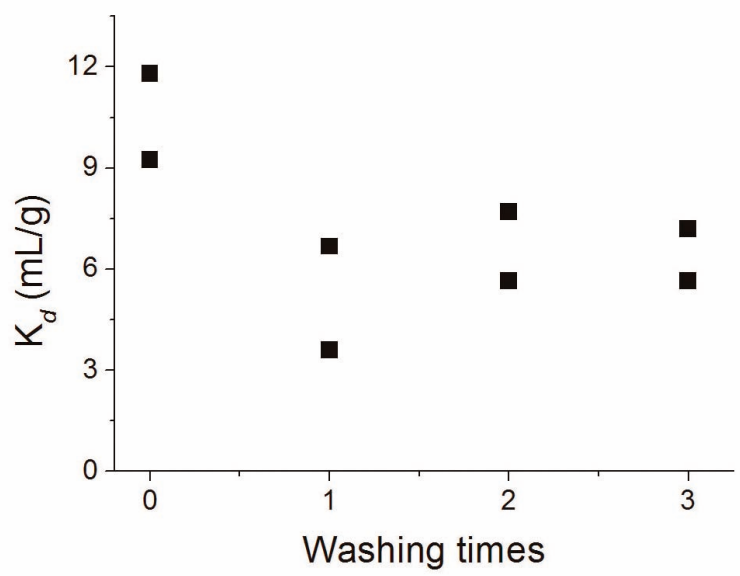

Fig. 3. Distribution Coefficients $\left(\mathrm{K}_{\mathrm{d}}\right)$ of Selenite onto Bentonite as a Function of Washing Times at Initial Selenite Concentration $=1 \times 10^{-5} \mathrm{~mol} / \mathrm{L}$, Water $/$ Bentonite $=40 \mathrm{~mL} / \mathrm{g}$ and $\mathrm{pH}=\sim 8.6$.

is decreased/reduced by the formation of a precipitant with soluble cations released from bentonite, the precipitates can barely be formed in the repository since released soluble cations might be flow out of the container during its expected 1,000 year lifespan. The $K_{d}$ values of selenite onto bentonite washed to remove soluble ions are shown Fig. 3. In this figure, a little amount of selenite was still sorbed onto the washed bentonite, while the $\mathrm{K}_{\mathrm{d}}$ values decreased after the initial wash. These results indicate that benonite itself sorbs selenite.

\section{CONCLUSIONS}

Selenite sorbed onto commercial magnetite very well in solutions around $\mathrm{pH}$ 9, while silicates hinder the sorption of selenite. Unlike commercial magnetite, flesh synthesized 
magnetite and green rust greatly decreased selenium concentration even in a silicate solution below $\mathrm{Eh}=-0.2$ $\mathrm{V}$. Iron powder also decreased the selenium concentration to less than the solubility of elemental $\mathrm{Se}$ or $\mathrm{FeSe}_{\mathrm{x}}$ under a reducing condition, and a red-colored $\mathrm{Se}(\mathrm{cr})$ was formed on the surface of the reaction bottle with the iron powder added into a selenite solution. The larger decrease in selenium concentrations caused by iron powder in $1 \times 10^{-3}$ $\mathrm{mol} / \mathrm{L}$ of silicate solution indicates that $\mathrm{HSe}^{-}$has a sorption affinity that favors iron greater rather than silicate. From the sorption results of selenite onto the iron and iron compounds, the migration of selenium in the waste repository would be dependent on the oxidation state of the contacting metal corrosion products, selenium species, and redox potential and anion concentration of groundwater. The sorption of selenite onto both virgin and washed bentonite even at a low concentration of $\left(10^{-6} \mathrm{~mol} / \mathrm{L}\right)$ suggests that the sorption of selenite by bentonite cannot be ignored in waste repositories.

\section{REFERENCES}

[1] Y. S. Hwang and C. H. Kang, "The Development of a Safety Assessment Approach and Its Implication on the Advanced Nuclear Fuel Cycle," Nucl. Eng. Technol., 42, pp. 37-46 (2010).

[2] N. K. Ishikawa, Y. Nakamaru, K. Tagami and S. Uchida, "Sorption Behavior of Selenium on Humic Acid under Increasing Selenium Concentration or Increasing Solid/ Liquid Ratio," J. Environ. Radioactivity, 99, pp. 993-1002 (2008).

[3] G. Jorg, R. Buhnemann, S. Hollas, N. Kivel, K. Kossert, S. Van Winckel, V. Lierse and Ch. Gostomski, "Precipitation of Radiochemically Pure ${ }^{79} \mathrm{Se}$ and Highly Precise Determination of Its Half-life," Appl. Radiat. Isotopes, 68, pp. 23392351 (2010).

[4] N. Jordan, C. Lomenech, N. Marmier, E. Giffaut and J. J. Ehrhart, "Sorption of Selenium(IV) onto Magnetite in the Present of Silicic Acid," Colloid Inter. Sci., 329, pp. 17-23 (2009).

[ 5 ] A. C. Scheinost, R. Kirsch, D. Banerjee, A. FernandezMartinez, H. Zaenker, H. Funke and L. Charlet, "X-ray Absorption and Photoelectron Spectroscopy Investigation of Selenite Reduction by Fe(II)-Bearing Minerals," Contam. Hydrol., 102, pp. 228-245 (2008).

[6] M. Martınez, J. Gimenez, J. de Pablo, M. Rovira and L. Duro, "Sorption of Selenium(IV) and Selenium(VI) onto Magnetite,” Appl. Surf. Sci., 252, pp. 3767-3773 (2006).

[ 7 ] M. Duc, G. Lefèvre and M. Fédoroff, "Sorption of Selenite Ions on Hematite," Colloid Inter. Sci., 298, pp. 556-563 (2006).

[ 8 ] M. Rovira, J. Giménez, M. Martinez, X. Martinez-Llado, J. de Pablo, V. Marti and L. Duro, "Sorption of Selenium (IV) and Selenium(VI) onto Natural Iron Oxides: Goethite and Hematite," J. Hazard. Mater., 150, pp. 279-284 (2007).

[9] C. Su and D. L. Suarez, "Selenate and Selenite Sorption on Iron Oxides; An Infrared and Electrophoretic Study," Soil Sci. Soc. Am. J., 64, pp. 101-111 (2000).

[10] L. Charlet, A. C. Scheinost, C. Tournassat, J. M. Greneche, A. Gehin, A. Fernandez-Martınez, S. Coudert, D. Tisserand and J. Brendle, "Electron Transfer at the Mineral/Water Interface: Selenium Reduction by Ferrous Iron Sorbed on Clay," Geochim. Cosmochim. Acta, 71, pp. 5731-5749 (2007).

[11] T. Missana, U. Alonso, A. C. Scheinost, N. Granizo and M. Garcia-Gutierrez, "Selenite Retention by Nanocrystalline Magnetite: Role of Adsorption, Reduction and Dissolution /Coprecipitation Processes," Geochim. Cosmochim. Acta, 73, pp. 6205-6217 (2009).

[12] S. S. Kim, K. S. Chun, K. C. Kang, M. H. Baik, S. H. Kwon and J. W. Choi, "Estimation of the Corrosion Thickness of a Disposal Container for High-Level Radioactive Wastes in a Wet Bentonite," J. Ind. Eng. Chem., 13(6), pp. 959964 (2007).

[13] L. Balistrieri and T. T. Chao, "Selenium Adsorption by Goethite," Soil Sci. Soc. Am. J., 51, pp. 1145-1151 (1987).

[14] L. Balistrieri and T. T. Chao, "Adsorption of Selenium by Amorphous Iron Oxyhydroxides and Manganese Dioxide," Geochim. Cosmochim. Acta, 54, pp. 739-751 (1990).

[15] F. Dang, N. Enomoto, J. Hojo and K. Enpuku, "Sonochemical Synthesis of Monodispersed Magnetite Nanoparticles by Using an Ethanol-Water Mixed Solvent," Ultrason. Sonochem., 16, pp. 649-654 (2009).

[16] A. G. B. Williams and M. M. Scherer, "Kinetics of Cr(VI) Reduction by Carbonate Green Rust," Environ. Sci. Technol., 35, pp. 3488-3494 (2001).

[17] S. Kaufhold, M. Pohlmann-Lortz, R. Dohrmann and R. Nüesch, "About the Possible Upgrade of Bentonite with Respect to Iodide Retention Capacity," Appl. Clay Sci., 35, pp. 39-46 (2007).

[18] G. Alfthan, D. Wang, A. Area and J. Soverib, "The Geochemistry of Selenium in Groundwaters in Finland," The Science of the Total Environment, 162, pp. 93-103 (1995).

[19] C. Mayant, B. Grambow, A. Abdelouas, S. Ribet, and S. Leclercq, "Surface Site Density, Silicic Acid Retention and Transport Properties of Compacted Magnetite Powder," Phys. Chem. Earth, 33, pp. $991-999$ (2008).

[20] Morihiro Mihara, "Radio-Nuclide Migration Databases (RAMDA) for the Safety Assessment of TRU Waste Repositories in Japan," JAEA-review-2006-011, Japan Atomic Energy Agency, Japan (2006).

[21] Y. Iida, T. Yamaguchi, T. Tanaka and S. Nakayama, "Solubility of Selenium at High Ionic Strength under Anoxic Conditions," J. Nucl. Sci. Tech., 47(5), pp. 431-438 (2010).

[22] F. Seby, M. Potin-Gautier, E. Giffaut, G. Borge and O. F. $X$. Donard, "A Critical Review of Thermodynamic Data for Selenium Species at $25^{\circ}$ C," Chem. Geol., 171, pp. 173 -194 (2001).

[23] L. Duro, M. Grivé, E. Cera, C. Domènech and J. Bruno, "Update of a Thermodynamic Database for Radionuclides to Assist Solubility Limits Calculation for Performance Assessment," SKB-TR-06-17, Stockholm, Sweden (2006).

[24] P. D. Cannière, A. Maes, S. Williams, C. Bruggeman, T. Beauwens, N. Maes and M. Cowper, "Behavior of Selenium in Boom Clay," External Report, SCK•CEN-ER-120, Mol, Belgium (2010).

[25] I. McKinley and D. Savage, "Comparison of Solubility Databases Used for HLW Performance Assessment," $J$. Contam. Hydrol., 21, pp. 335-350 (1996).

[26] Y. Fujikawa and M. Fukui, "Radionuclide Sorption to Rocks and Minerals: Effects of $\mathrm{pH}$ and Inorganic Anions. Part 2. 
Sorption and Speciation of Selenium," Radiochim. Acta, 76, pp. 163-172 (1997).

[27] R. L. de Loyo, S. I. Nikitenko, A. C. Scheinost and M. Simonoff, "Immobilization of Selenite on $\mathrm{Fe}_{3} \mathrm{O}_{4}$ and $\mathrm{Fe} /$ $\mathrm{Fe}_{3} \mathrm{C}$ Ultrasmall Particles," Environ. Sci. Technol., 42, pp. 2451-2456 (2008).

[28] A. M. Scheidegger, D. Grolimund, D. Cui, J. Devoy, K. Spahiu, P. Wersin, I. Bonhoure and M. Janousch, "Reduction of Selenite on Iron Surfaces: a Micro-Spectroscopic Study," Phys. IV, 104, pp. 417-420 (2003).

[29] A. C. Scheinost and L. Charlet, "Selenite Reduction by Mackinawite, Magnetite and Siderite: XAS Characterization of Nanosized Redox Products," Environ. Sci. Technol., 42, pp. 1984-1989 (2008).

[30] C. Bruggeman, A. Maes, J. Vancluysen and P. Vandemussele, "Selenite Reduction in Boom clay: Effect of $\mathrm{FeS}_{2}$, Clay Minerals and Dissolved Organic Matter," Environ. Pollut., 137, pp. 209-221 (2005).

[31] E. Breynaert, C. Bruggeman and A. Maes, "XANES-EXAFS Analysis of Se Solid-Phase Reaction Products Formed upon Contacting Se(IV) with FeS2 and FeS," Environ. Sci. Technol., 42, pp. 3595-3601 (2008).

[32] K. Daub, X. Zhang, J. J. Noel and J. C. Wren, "GammaRadiation-Induced Corrosion of Carbon Steel in Neutral and Mildly Basic Water at $150^{\circ} \mathrm{C}, "$ Corros. Sci., 53, pp. 11-16 (2011). 